\title{
PENGEMBANGAN PROFESIONALISME GURU
}

\author{
Rifqa Rahmatunnisa
}

Email: rifqarahmatunnisa@gmail.com

\begin{abstract}
ABSTRAK
Dilakukan penelitian dan survey untuk mengetahui gambaran mengenai pengembangan profesi guru, gambaran tingkat kinerja guru dan pengaruh pengembangan profesi guru terhadap kinerja guru. Metode yang digunakan dalam penelitian ini adalah metode survey. Teknik pengumpulan data dalam penelitian ini menggunakan angket. Yang menjadi objek penelitian ini adalah 21 orang guru tetap SMK di Bandung. Hasil penelitian menunjukkan pengembangan profesi guru berada dalam kategori cukup efektif dan kinerja guru berada pada kategori cukup tinggi. Hasil belajar dan prestasi siswa di indonesia belum memuaskan dibandingkan dengan negara-negara lainnya. Hal ini disebebkan oleh kurang optimalnya kinerja guru dalam proses pembelajaran. Penelitian berfokus untuk membahas tentang proses pengembangan profesi guru untuk meningkatkan kinerjanya dan menghasilkan proses pembelajaran yang baik guna untuk meningkatkan prestasi dan hasil belajar siswa kedepannya.
\end{abstract}

Kata Kunci: pengembangan profesionalisme guru, kinerja guru

\section{LATAR BELAKANG}

Dalam meraih mutu pendidikan yang baik dipengaruhi oleh kinerja guru dalam melaksanakan tugasnya. Guru adalah komponen yang penting dalam terselenggaranya pendidikan Secara umum mutu pendidikan menjadi tolok ukur keberhasilan pendidikan Supervisi adalah pengawasan yang dilakukan secara profesional digunakan sebagai usaha untuk memberi layanan baik secara individual atau perseorang maupun memberikan layanan secara berkelompok 
kepada guru-guru guna untuk memperbaiki atau meningkatkan kinerja guru agar menjadi guru yang profesional.

Supervisi disini sangat berperan penting dalam pengembangan profesionalisme guru. Dimana supervisi digunakan untuk meningkatkan proses dan hasil belajar yang memerlukan motivasi yang kuat dari seorang guru, maka dari itu seorang supervisor perlu melakukan berbagai upaya untuk mengambangkan profesionalisme guru yang di supervisinya tersebut. Salah satu upaya yang dapat dilakukan dalam peningkatan profesional guru adalah melalui proses belajar mengajar.

Supervisor memegang peranan penting dalam meningkatkan kualitas guru agar dapat melaksanakan pembelajaran yang lebih berkualitas. Dimensi kompetensi supervisi kepala sekolah sebagaimana dikemukakan oleh Sabandi(Sabandi, 2013) meliputi :(1) merencanakanprogram supervisi akademik dalam rangkapeningkatan profesionalisme guru, (2)melaksanakan supervisi akademik terhadap gurudengan menggunakan pendekatan dan teknik.

\section{PEMBAHASAN}

\section{Pengembangan Profesi Guru}

Pengambangan profesional guru diartikan sebagai suatu kegiatan yang dilakukan untuk mengetahui apakah kemampuan guru dangan tuntutan pendidikan saat ini sesuai dengan keahlian dan keterampilan yang dimiliki oleh guru tersebut. Pengembangan ini diarahkan untuk melakukan prningkatan pada kinerja guru dilingkungan sekolah, penilai dari kinerja guru yang dilakukan secara objektif, transparan dan akuntabilitas, serta mendorong untuk meningkatkan prestasi dari guru tersebut.

Menurut Putri ayu(Putri, 2017) dalammeraihmutupendidikanyang baiksangatdipengaruhiolehkinerjaguru dalam melaksanakan tugasnyasehingga kinerjaguru menjadi tuntutan penting untukmencapai keberhasilan 
pendidikan. Secara umum mutu pendidikan yang baik menjadi tolok ukur bagi keberhasilan kinerjayang ditunjukkan guru

Pengembangan profesi seorang pendidik merupakan suatu yang sangat penting, dimana pengembangan merupakan pertumbuhan secara umum yang tidak terfokus pada pekerjaan tertentu. Pengembangan profesi guru mengklasifikasikan beberapa indikator dalam pengembangan profesi tersebut, diantaranya:

1. Mengikuti informasi sesuai perkembangan IPTEK yang menjadi pendukung dari profesi tersebut

2. Menggunakan berbagai metode pembelajaran yang bervariasi

3. Menggunakan media sebagai alat peraga

4. Mengikuti perkembangan kurikulum yang selalu berkelanjutan

Pengembangan profesi guru merupakan suatu proses kegiatan yang berjalan terus menerus. Guru atau pendidik merupakan sesuatu paling penting dalam proses pendidikan, sehingga kualitas pendidikan banyak ditentukan oleh kualitas seorang pendidik ketika menjalankan tugasnya.

\section{Kinerja Guru}

Kinerja guru adalah suatu hasil atau kemampuan guru dalam menunjukkan keahlian atau potensi yang dimilikinya. Kinerja guru juga merupakan suatu bentuk dari hasil usaha seorang pendidik untuk mencapai tujuan pendidikan.

Kinerja guru adalah suatu proses pembelajaran sebagai upaya dalam mengembangkan suatu kegiatan yang telah ada untuk menjadi kegiatan yang lebih baik, sehingga tujuan pendidikan yang telah ditentukan dapat tercapai melalui kegiatan pembelajaran yang dilakukan dengan tujuan atau terget yang telah ditentukan.

Upaya yang dapat dilakukan dalam meningkatkan kinerja guru yaitu: melaksanakan pembinaan akademik kepada guru-guru, memberikan tambahan tugas pada guru baru dan memberikan penghargaan atau reward kepada guru yang berpartisipasi dan memberikan hukuman kepada guru yang malas serta tidak melaksanakan tugas dengan baik. 


\section{PENUTUP}

\section{Kesimpulan}

Supervisi adalah pengawasan yang dilakukan secara profesional dalam bidang akademik yang dilakukan berdasarkan pedoman keilmuan tentang dibidang kerja tertentu, dan mengetahui tentang proses pembelajaran untuk lebih mendalaminya, serta digunakan untuk melakukan layanan secara baik kepada individu baik secara kelompok maupun secara perorangan kepada guru untuk meningkatkan profesionalisme dan kinerja dari guru tersebut.

Pengembangan profesionalisme guru diartikan sebagai suatu kegiatan yang dilakukan untuk mengetahui apakah kemampuan guru dangan tuntutan pendidikan saat ini sesuai dengan keahlian dan keterampilan yang dimiliki oleh guru tersebut.Peningkatan kinerja guru dilakukan untuk meningkatkan dan mengambangkan potensi yang ada pada guru tersebut yang dilakukann dalam jangka waktu yang lama dan dilakukan secara terus menerus atau berelanjutan.

\section{Saran}

Diharapkan kepada pembaca setelah memahami isi dari laporan analisis jurnalini agar dapat memahami tentang pengembangan profesional guru dalam meningkatkan kinerja guru.

\section{REFERENSI}

Putri, ayu dwi kesuma. (2017). Pengembangan profesi guru dalam meningkatkan kinerja guru. PENDIDIKAN MANAJEMEN PERKANTORAN, 1(1), 1-9. Retrieved from ejournal.upi.edu/index.php/jpmanper/article/download/...

Sabandi, A. (2013). SUPERVISI PENDIDIKAN UNTUK PENGEMBANGAN PROFESIONALITAS GURU BERKELANJUTAN. Pedagogi, Jurnal Ilmiah Ilmu Pendidikan, XIII(2), 1-9. Retrieved from http://ejournal.unp.ac.id/index.php/pedagogi/article/view/4275 
